\title{
PIGMENTED BASAL CELL CARCINOMA - AN UNUSUAL PRESENTATION AND ITS MANAGEMENT
}

\author{
Gautam Paul ${ }^{1}$, Nilanjan Thakur ${ }^{2}$, Nagesha C.K³, Chanchal Poddar ${ }^{4}$, Pranab Chakraborty ${ }^{5}$
}

\section{HOW TO CITE THIS ARTICLE:}

Gautam Paul, Nilanjan Thakur, Nagesha CK, Chanchal Poddar, Pranab Chakraborty. "Pigmented basal cell carcinoma - an unusual presentation and its management". Journal of Evolution of Medical and Dental Sciences 2013; Vol2, Issue 37, September 16; Page: 7066-7068.

CASE SUMMARY: A 45year old lady presented to outpatient clinic with pain \& swelling in the medial canthal area and watering from Left eye simulating acute dacryocystitis. Patient was treated for the same but with no response. After 4-5visits, she developed non healing ulcer over the same area. The patient was otherwise healthy, with no history of excessive sun exposure or any predisposing factors for skin cancer.

Examination revealing $2 \mathrm{~cm} \times 2 \mathrm{~cm}$ ulcer with slightly elevated pigmented margin (fig: 1 ) involving the puncta posed a real diagnostic dilemma.

The lesion was subjected for excisional biopsy with $3 \mathrm{~mm}$ clear margin under local anaesthesia. As the punta were also involved, a medial $25 \%$ of full thickness lid was excised along with main lesion (Fig: 2). Concomitant dacryocystectomy was carried out.

Canthal reconstruction was done followed by direct approximation of lid defects to newly formed canthus. A myo cutaneous glabellar flap was transposed to the defect area with inverted V-Y closure (fig: 3 ).

Histopathological examination under low power showed solid islands of tumor cells with peripheral palisading; there is also a clefting artifact in between the stroma and epithelium. High power shows pigments within solid highland basal cells and in macrophages suggestive of pigmented basal cell carcinoma.

1 month Postoperative period was uneventful, with acceptable cosmetic appearance.

Unusual presentation of pigmented chronic ulcer with watering in a middle aged lady diverted our attention towards non-malignant pathology resulting in erroneous initial diagnosis \& treatment.

DISCUSSION: Basal cell carcinomas (BCC) are the most common malignant neoplasms in humans. Clinical misdiagnoses are not uncommon. It is the most common cancer among Caucasians, being three to six times more frequent than squamous cell carcinoma (SCC) ${ }^{1}$. Approximately $5 \%-10 \%$ of all skin cancers occur in the eyelid and BCC accounts for $\sim 80 \%-90 \%$ of all nonmelanoma skin cancers affecting the periocular area².

Pigmented BCC is rare representing close to $1 \%$ of eyelid's BCC. Pigmentary deposits of melanin can mimic a nodular melanoma or atypical nevi3 ${ }^{3}$. Azzam et al reported an unusual case of combined pedunculated and pigmented basal cell carcinoma which he rarely encountered ${ }^{4}$.

Clinical behaviour of BCC is highly variable. It can present as nodular, ulcerative, chronic dermatitis, atypical nevi etc. Baker $\mathrm{HE}^{5}$ reported a case of BCC that presented as ectropion, then entropion, and finally medial canthal dystopia. An inflammatory mass with watering in our case resulted in erroneous diagnosis, a pigmented ulcer which developed later again mislead us from thinking of BCC. 
Excision of upper eyelid skin cancer often leads to moderate to large defect. Numerous procedures are available to reconstruct such defects. Yan J et al 6 described tarso conjunctival flap and skin flaps for skin carcinoma on his left medial canthus, which also involved medial tarsal palate of the upper eyelid.

Other type of flaps like tunneled forehead flap ${ }^{7}$, Triple-flap medial canthal reconstruction ${ }^{8}$, glabellar flap modification "flap in flap" technique ${ }^{9}$, Radix nasi transposition flap ${ }^{10}$ have been described in literature for varying amount of defects with satisfactory results.

In present case, a combined transposition flap with lid defect closure appealed to be a viable option in extensive lid and canthal defects.

CONCLUSION: Clinical misdiagnoses of BCC are not uncommon. They exhibit distinct malignant behaviours hence it is important to be aware of the different clinical presentations both for the accurate diagnosis and tumour management. A combined reconstruction reported in this present case a valuable technique in large defects.

\section{REFERENCES:}

1. Aurora AL, Blodi FC.: Reappraisal of basal cell carcinoma of the eyelids. Am J Ophthalmol. 1970 Sep; 70(3):329-36.

2. Margo CE, Waltz K: Basal cell carcinoma of the eyelid and periocular skin. Surv Ophthalmol 1993; 38:169-192.

3. Hornblass A, Stefano JA: Pigmented basal cell carcinoma of the eyelids. Am J Ophthalmol 1981; 92:193-197.

4. Azzam C, Arrese JE, Jacquemin D, Calteux N, Piérard GE [Pedunculated and pigmented basal cell carcinoma: an unusual presentation]. Rev Med Liege. 2006 Sep; 61(9):614-6.

5. Baker HE, Berry-Brincat A, Zaki I, Cheung D. Three different consecutive manifestations of morphoeic BCC in the same patient: presenting first as ectropion, then entropion, and finally medial canthal dystopia with epicanthus inversus. Orbit. 2008; 27 (3):183-5.

6. Yan J, Liu L, Qian J. Reconstruction of upper eyelid and medial canthus following basal cell carcinoma resection: a successful one-stage repair with three local flaps. Int J Dermatol. 2013 May; 52(5):611-3.

7. Mombaerts I, Gillis A. The tunneled forehead flap in medial canthal and eyelid reconstruction. Dermatol Surg. 2010 Jul; 36(7):1118-25.

8. Berry MG, Fernandes AE. Triple-flap medial canthal reconstruction. Can J Plast Surg. 2008 Fall; 16 (3):170-2.

9. Turgut G, Ozcan A, Yeşiloğlu N, Baş L. A new glabellar flap modification for the reconstruction of medial canthal and nasal dorsal defects: "flap in flap" technique. J Craniofac Surg. 2009 Jan; 20 (1):198-200.

10. Carvalho R, Casal D, Zagalo C, Rosa J. Radix nasi transposition flap for medial canthus and nasal sidewall defects. Dermatol Surg. 2011 Dec; 37(12):1777-80. 


\section{CASE REPORT}

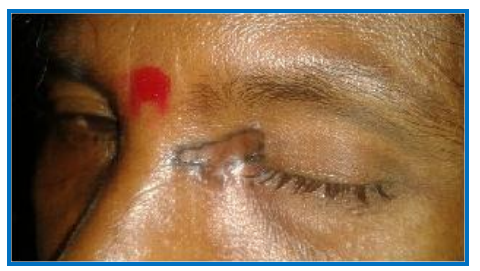

Fig. 1

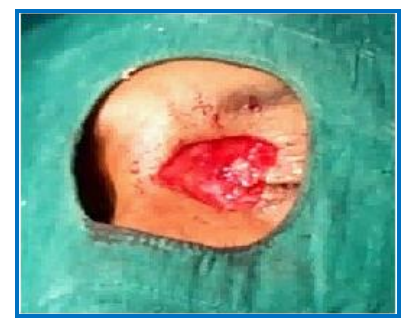

Fig. 2

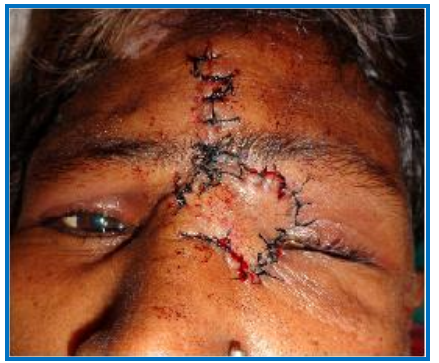

Fig. 3

\section{AUTHORS:}

1. Gautam Paul

2. Nilanjan Thakur

3. Nagesha C.K.

4. Chanchal Poddar

5. Pranab Chakraborty

\section{PARTICULARS OF CONTRIBUTORS:}

1. Assistant Professor, Department of Ophthalmology, Silchar Medical College and Hospital.

2. Medical Officer, Department of Ophthalmology, Silchar Medical College and Hospital.

3. Post Graduate, Department of Ophthalmology, Silchar Medical College and Hospital.

4. Post Graduate, Department of Ophthalmology, Silchar Medical College and Hospital.
5. Post Graduate, Department of Ophthalmology, Silchar Medical College and Hospital.

\section{NAME ADDRESS EMAIL ID OF THE CORRESPONDING AUTHOR:}

Dr. Gautam Paul, Assistant Professor, Department of Ophthalmology,

Silchar Medical College and Hospital,

Silchar - 788014.

Email -drgpaul59@yahoo.com

Date of Submission: 01/09/2013.

Date of Peer Review: 02/09/2013.

Date of Acceptance: 06/09/2013.

Date of Publishing: 10/09/2013 